\title{
New simple trichal cyanobacterial taxa isolated from radioactive thermal springs
}

\author{
Fatemeh Heidari ${ }^{1}$, Jan Zima JR. ${ }^{2}$, Hossein Riahi ${ }^{1} \&$ Tomáš HaUer ${ }^{2,3 *}$
}

\author{
${ }^{I}$ Faculty of Life Sciences and Biotechnology, Shahid Beheshti University, Tehran, Iran. \\ ${ }^{2}$ Institute of Botany AS CR, Centre for Phycology, Dukelská 135, Třebon̆, CZ-37982, Czech Republic \\ ${ }^{3}$ Faculty of Science, University of South Bohemia, Branišovská 1760, České Budějovice, CZ-37005, Czech \\ Republic
}

\begin{abstract}
There are several places in the world where the level of natural radiation is unusually high, such as some regions of Ramsar and Abegarm-e-Mahallat in Iran. Such places are still insufficiently explored in terms of their biodiversity. In this study, strains isolated from six geothermal springs with elevated natural radiation were investigated. The highest concentration of ${ }^{226} \mathrm{Ra}$ were $13,000 \mathrm{~Bq} \cdot \mathrm{kg}^{-1}$ in the soil and $130 \mathrm{~Bq} \cdot \mathrm{l}^{-1}$ in water respectively. The morphological and molecular analyses revealed, that the strains are not classifiable to any existing taxon. Therefore, they are described as new taxa for science. Based on results of our study, two earlier described species are transferred into newly established genus.
\end{abstract}

Key words: Cyanobacteria, High-level natural radiation areas, thermal springs, ${ }^{226} \mathrm{Ra}$, Ramsar, Iran

\section{INTRODUCTION}

Major components of natural ionizing radiation sources are cosmic radiation sources and terrestrial radiation sources. Radiation exposure from terrestrial sources includes external and internal irradiation. Internal irradiation because of inhalation of radium $\left({ }^{226} \mathrm{Ra}\right)$ progenies (e.g., radon and thoron) and ingestion of ${ }^{228} \mathrm{U}$ and ${ }^{232} \mathrm{Th}$ decay series is the main dose participant compared to the external irradiation of terrestrial gamma radiation (TGR). The irradiation of TGR is mainly due to various $\gamma$ radiation emitters from primordial radionuclides of ${ }^{226} \mathrm{Ra},{ }^{232} \mathrm{Th}$ series and ${ }^{40} \mathrm{~K}$ in soil. In fact, diffusion of radionuclide concentrations is associated with local geology and geographical factors of places (SANUCI et al. 2016).

Organisms inhabiting the world's High Background Natural Radiation Areas (HBNRAs) and radon prone areas are exposed to radiation doses that are relatively higher than doses in normal background radiation areas (NBRAs) (SoHRABI 2013b). Some of the world's HBNRAs are located in Kerala (India), Guarapari (Brazil), Yangjiang (China) and Ramsar and Mahallat (Iran) (MorTAZAVI et al. 2002; MorTAZAVI \& MoZDARANI 2012).

The world's HBNRAs have been classified on the basis of inhabitants' annual effective dose (HE): low $\left(\mathrm{HE}<5 \mathrm{mSv} \cdot \mathrm{y}^{-1}\right)$, medium $\left(\mathrm{HE}=5-10 \mathrm{mSv} \cdot \mathrm{y}^{-1}\right)$, high
$\left(\mathrm{HE}=20-50 \mathrm{mSv} \cdot \mathrm{y}^{-1}\right)$ and very high $\left(\mathrm{HE}>50 \mathrm{mSv} \cdot \mathrm{y}^{-1}\right)$ (SoHrabi 1998). This grouping is based on the dose limits of the International Commision on Radiological protection (hereafter ICRP) and the $2.4 \mathrm{mSv} \cdot \mathrm{y}^{-1}$ global mean dose value reported by UNSCEAR (ICRP 1991, 2007; UNSCEAR 2000a, b). Specific characteristics of HBNRAs depend on the stability of natural radioactivity. There are areas in which the radiation dose is constant over time and other areas in which the dose varies with time (SoHrabi 2013a).

Ramsar, the city in northern Iran, is a high-level natural radiation area and Mahallat, the city in central part of Iran, is a medium-level natural radiation area. The elevated level of natural radioactivity in Ramsar and Mahallat is caused by ${ }^{226} \mathrm{Ra}$ and its decay products, which have been brought up to the earth's surface by water of thermal springs. There are nine and five geothermal springs with varying concentration of radium $\left.{ }^{226} \mathrm{Ra}\right)$ in Ramsar and Mahallat respectively, which are used as spas (SoHrabi 1993, 1994; GHIASSI-NEJAD et al. 2002; AliYu \& RamLi 2015).

Geothermal springs are great examples of extreme habitats for organisms with 'subcosmopolitan' geographical distribution (species occurring throughout the world but only in 'appropriate' habitats) (FInSINGER et al. 2008). The hot spring mat communities in terrestrial habitats, as life in extreme environments, have long enticed the consideration of microbial 
ecologists because of unique adaptations, diversity of organisms and molecular and regulatory mechanisms to these harsh environments (ZAKARIA et al. 2008; GLAZIER 2009).

Products acquirable from extremophiles, such as proteins, enzymes and other compounds, are of significant interest to biotechnology. This field of research has also attracted attention due to its impact on the possible existence of life on other planets. (SATYANARAYANA et al. 2005).

Microorganisms have been isolated from extreme environments ranging from the drought conditions in the Atacama Desert (JAAKKOLA et al. 2016), sea-ice brine and high salinity (LIU et al. 2016), and hot springs (GEESEY et al. 2016). These microorganisms have unique strategies for survival (SHIVLATA et al. 2015).

Cyanobacteria show vast diversity in terms of their morphology, habitat and functionalities (BECH et al. 2012), which are reflected in their genome and/ or other related genomic features (e.g., genome size, coding region, GC content). PRABHA et al. (2016) investigated cyanobacterial genomes and their role in environmental adaptations. They showed that habitat is one of the major factors in giving the shape to the functional composition of cyanobacterial genomes towards their ecological adaptations. The cell envelopes in cyanobacteria play a critical role in their adaptation to higher temperatures, especially the cell structure and function (RAHMAN et al. 2008). Among phototrophic microorganisms, Cyanobacteria are an important source of various products of commercial, toxicological and pharmaceutical interest. They are believed to be one of the richest sources of novel bioactive compounds (MAHAJAN et al. 2016).

Cyanobacterial composition of microbial mats from other hot springs have been studied extensively (e.g. Castenholz 1996; Ward et al. 1998, 2012; SOMPONG et al. 2005; JiNG HongMEI et al. 2005; Roeselers et al. 2007; McGregor \& PAul Rasmussen 2007; FINSINGER et al. 2008; Oren et al. 2009; SIANGBOOD et al. 2011; DADHEECH et al. 2013; GHOZZI et al. 2013; BravaKos et al. 2016), but data from radioactive thermal springs are rather scarce. Some data from such habitat are provided e.g. by ANITORI et al. (2000)

Cyanobacterial community living in geothermal springs in the HBNRAs in Iran are special extermophilic microorganisms. They are involved in a landscape-forming process that creates unique environments with a variety of microenvironments, which, in turn, support diverse specialized and poly-extremophilic (thermophilic/radioresistant) organisms. Despite this, biodiversity of cyanobacteria in geothermal springs in HBNRA in Iran has not been studied up to now. This study aimed to isolate, cultivate and characterize novel cyanobacterial strains that colonize hot springs in HBNRAs in Iran. The taxonomic position of the isolates was evaluated by morphological and molecular phylogenetic analyses. In this study, not only an attempt has been made to investigate the radioresistant cyanobacterial communities, but also new cyanobacterial taxa that occur in extreme environments of thermal springs in HBNRAs in Iran have been introduced, which will be invaluable for their adaptations and potential biotechnological applications.

To the best of our knowledge, this is the first report on the cyanobacterial diversity isolated from HBNRAs in Iran.

\section{Material And Methods}

Site description and sample collection. In this study, water and soil samples were collected from 10 thermal springs near Ramsar (Mazandaran Province, Iran) and Mahallat (Markazi Province, Iran), which are known as HBNRAs (areas known to have the highest ${ }^{226} \mathrm{Ra}$ and gamma exposure levels in Iran). Geographically, Ramsar is located at $36^{\circ} 53^{\prime} \mathrm{N} 50^{\circ} 41^{\prime} \mathrm{E}$, with an average altitude of $20 \mathrm{~m}$ a.s.1. (SOHRABI 2013b). The other studied area, Mahallat, is located at $34^{\circ} 00^{\prime} \mathrm{N} 50^{\circ} 33^{\prime} \mathrm{E}$, with an average altitude of $1860 \mathrm{~m}$ a.s.l. (BEITOLLAHI et al. 2007). Water samples were collected via the method of DADHEECH et al. (2013) for culturing cyanobacteria. For the purpose of the chemical analysis, the water samples were stored in polyethylene containers previously conditioned with $0.03 \mathrm{~mol}^{-1^{-1}}$ $\mathrm{HNO}_{3}$ and stored at $4{ }^{\circ} \mathrm{C}$ until the usage. Soil samples were collected from the hot springs at a depth of $5 \mathrm{~cm}$ to determine their natural radionuclide content. The collected soil samples were sieved and dried.

${ }^{226}$ Ra determination and chemical analysis. Determination of the ${ }^{226} \mathrm{Ra}$ activity in the water samples was carried out via radon emanations, according to the procedure described by FORTE et al. (2004). ${ }^{226} \mathrm{Ra}$ was measured by measuring its daughter ${ }^{222} \mathrm{Rn}$ after reaching equilibrium with its parent (about 30 days). The method is based on ${ }^{222} \mathrm{Rn}$ extraction via a scintillation cocktail, immiscible in water, followed by measurement of the alpha and beta emissions, with a liquid scintillation counter, of the ${ }^{222} \mathrm{Rn}$ and its decay products in radioactive equilibrium with the parent.

The collected soil samples were held in sealed Marinelli beakers for a minimum of three weeks (the time required to achieve secular equilibrium between ${ }^{226} \mathrm{Ra}$ and its daughter products). The ${ }^{226} \mathrm{Ra}$ activity of the soil samples was consummated by direct gamma spectrometry (at 186 $\mathrm{keV}$ energy) using a high-purity Ge-detector and a multichannel analyzer. The counting time for all samples was set to $60,000 \mathrm{sec}$. Local spring water temperature was measured in situ using a laboratory thermometer (Mercury thermometer). Atomic absorption spectrophotometer (AAS, Varian AA-220) was applied to determine metals such as $\mathrm{Ca}^{2+}$, $\mathrm{Mg}^{+}, \mathrm{Mn}^{2+}, \mathrm{Ni}^{3+}, \mathrm{Na}^{+}$and $\mathrm{K}^{+}$in the water samples. The $\mathrm{pH}$ of the water samples was determined by a digital $\mathrm{pH}$ meter (DENVER pH meter), with the samples' electrical conductivity determined using a conductivity bridge. Measured values are listed in Table S1.

Isolation and Morphological evaluation of cyanobacteria. Water and soil samples were collected from 10 thermal springs across the areas selected for the study. The water 
samples were streaked on agar with BG-11 medium (Stanier et al. 1971). The Petri dishes were incubated in a culture chamber with the following parameters: $25{ }^{\circ} \mathrm{C}$ by application of $12 / 12 \mathrm{~h}$ light/dark cycles by artificial illumination (30 $\mu \mathrm{mol}$ photons. $\left.\mathrm{m}^{-2} . \mathrm{s}^{1}\right)$ for two weeks. After colonization, resulting isolates were transferred to new agar plates for purification. Isolated cyanobacterial strains were identified using the KomáreK and AnAgnostidis (1999, 2005), and KOMÁREK (2014). Taxonomic determination was carried out by light microscopy on Olympus BX 53.

DNA processing. The genomic DNA was isolated in accordance with the modified xanthogenate-SDS buffer extraction protocol with addition of $3 \% \mathrm{PVPP}$ and $\mathrm{PEG}-\mathrm{MgCl}_{2}$ precipitation (Yilmaz et al. 2009). A segment of partial SSU rRNA gene and the associated $16 \mathrm{~S}-23 \mathrm{~S}$ internal transcribed spacer (ITS) region was amplified using primer $1\left(5^{\circ}-\mathrm{CTC}\right.$ TGT GTG CCT AGG TAT CC-3') (Willmote et al. 1993) and primer 16S27F (5'-AGA GTT TGA TCC TGG CTC AG-3') (Lane et al. 1991). Each PCR reaction consisted of $12 \mu 1$ of Plain Combi PP Master Mix (Top-Bio, Czech Republic), $1 \mu \mathrm{l}$ of each primer $(\mathrm{c}=5 \mathrm{~nm}), 20-30 \mathrm{ng}$ of template DNA and $12 \mu \mathrm{l}$ of sterile bidestilled water. PCR protocol was as follows: 5 min of initial denaturation $\left(94^{\circ} \mathrm{C}\right)$, followed by 40 cycles of denaturation $\left(1 \mathrm{~min}\right.$ at $\left.94{ }^{\circ} \mathrm{C}\right)$, annealing $(45 \mathrm{~s}$ at $\left.52^{\circ} \mathrm{C}\right)$ and elongation $\left(2 \mathrm{~min}\right.$ at $\left.72{ }^{\circ} \mathrm{C}\right)$, and final extension for 10 minutes at $72{ }^{\circ} \mathrm{C}$. PCR products were cloned into E. coli using the pGEM-T Easy (Promega, Madison, WI, USA) vector system, and the resulting plasmids were purified using NucleoSpin Plasmid kit (Macherey-Nagel, Düren, Germany), and sequenced in SeqMe, s.r.o. (Dobrríš, Czech Republic) using standard plasmid primers (T7promoter and SP6r)

Phylogenetic analyses. In order to reveal phylogenetic relations of strains of interest to other simple trichal Cyanobacteria from orders Synechococcales and Oscillatoriales (sensu KomÁREK et al. 2014), the obtained sequences of the $16 \mathrm{~S}$ rRNA gene were analyzed together with other sequences available in main repositories (GenBank, EMBL ENA, DDBJ). Datasets have been built from the most similar sequences found using Blast Search and complemented with sequences of representatives of relevant simple trichal groups. The sequences were aligned using an on-line version of MAFFT v. 7 (http://mafft.cbrc.jp; КАТОН \& ТОН 2010) with default settings. Minor changes were done manually using BioEdit 7.1.9 (HALl 1999). A fragment of $1160 \mathrm{nt}$ was used for the phylogenetic analysis. In total, this alignment contained 284 sequences (all $>1000 \mathrm{bp}$ in length) including Gloeobacter violaceus PCC 7421, PCC8105 and VP3-01 as an outgroup. The pairwise sequence differences were calculated with Geneious 9.1.5 (Biomatters, Auckland, New Zealand). The phylogenetic analyses included maximum likelihood analysis using web IQTree (http://iqtree.cibiv. univie.ac.at/; TrifinOPOULOs et al. 2016), parsimony using MEGA 7 (KumAr et al. 2016) and Bayesian Inference in MrBayes 3.2.4 (RonQuist et al. 2012). In the Bayesian analysis, two runs of eight Markov chains were executed for four million generations with default parameters, sampling every 100 generations (the final average standard deviation of split frequencies was lower than 0.01 ) and first $25 \%$ of sampled trees were discarded as burn-in. The maximum likelihood analysis was conducted applying general time reversible model + invariant + gamma $(\mathrm{GTR}+\mathrm{I}+\Gamma)$ chosen according to Akaike Information Criterion values given by jModelTest2
(DARRIBA et al. 2012). The relative support of branches was determined by 1000 bootstrap pseudoreplicates. The secondary structures of D1-D1' and box B helices of the ITS region were predicted using Sfold application server (DING et al. 2004) version 2.2. Secondary structures folded for all newly described taxa are depicted in Figure 2.

\section{Results AND Discussion}

\section{Morphological evaluation of natural samples}

According to the morphological examination, Phormidium spp. and Leptolyngbya spp. together with Thermoleptolyngbya laminosa were found to be dominant genera in the hot springs and soil samples. The dominant morphotypes in benthos of the most radioactive spring in Ramsar were Leptolyngbya spp. and Nostoc spp., in addition the soil with highest radioactivity of 13000 Bq. $\mathrm{kg}^{-1}$ was settled by Cylindrospermum licheniforme. Morphological and molecular analyses revealed several new taxa to science. Comparison of our results with those reported by other authors is rather difficult, since we are not aware of any paper on cyanobacterial diversity in similar habitat. Some data provides the work by ANITORI et al. (2002) from Paralana hot spring in Australia, but only superficial. The spring also differs from those studied in this paper - in the source of radioactivity ( $\mathrm{Rn}$ instead of $\mathrm{Ra}$ ) and has higher temperature.

\section{New cyanobacterial taxa from thermal springs with high radioactivity}

\section{Plankthothrix iranica Heidari et Hauer sp. nov.} (Fig. 3A, B)

Description: Thallus macroscopic brown-green mats. Filaments solitary, isopolar, straight, dark blue-green or brown-green, without sheath. Trichomes cylindrical, motile, not constricted or very slightly constricted at the not granulated cross-walls, not attenuated to the ends. Cells 4-6 $\mu \mathrm{m}$ in width, shorter than wide or sometimes isodiametric, cell content blue-green, without aerotopes, and apical cells rounded, not tapered, nor capitate, without calyptra, with granular content mainly in older cells. Division by necridic cells and formation hormogonia.

Holotype here designated: CBFS A-82-1, an exsiccate of strain AS S8A

Habitat: Benthic mat in the thermal spring $\left(28^{\circ} \mathrm{C}\right)$ with high natural radioactivity, Abe siah, Ramsar, Iran. Etymology: the species is named after the country of its origin.

The strain is morphologically and by its benthic life form most similar to Planktothrix clathrata (Skuja) Anagnostidis et Komárek, but differs in motility and ecology, since Pl. clathrata has been described in lakes in Sweden. From other members of the genus this new species (Pl. iranica) differs in morphology - absence 

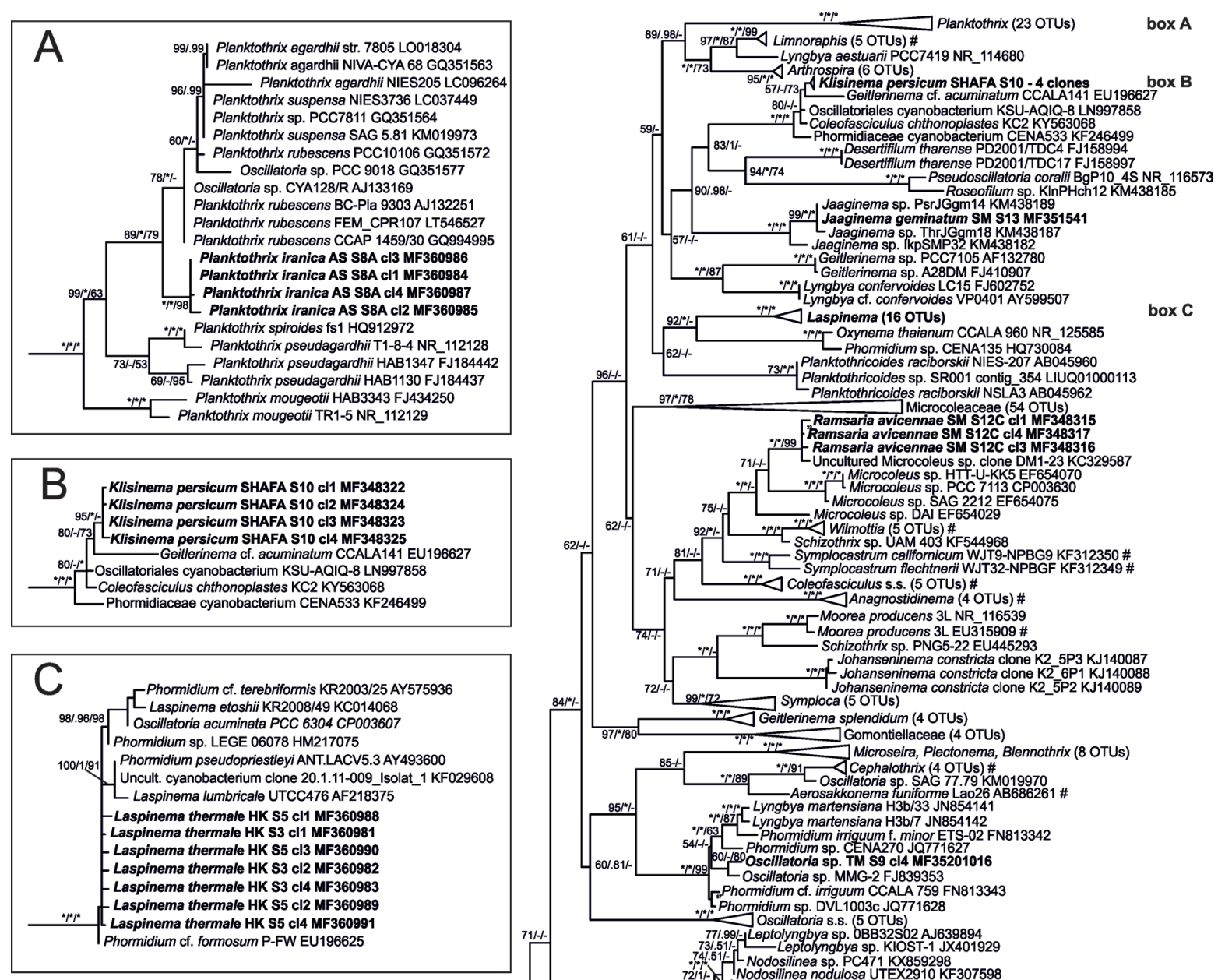

ox A
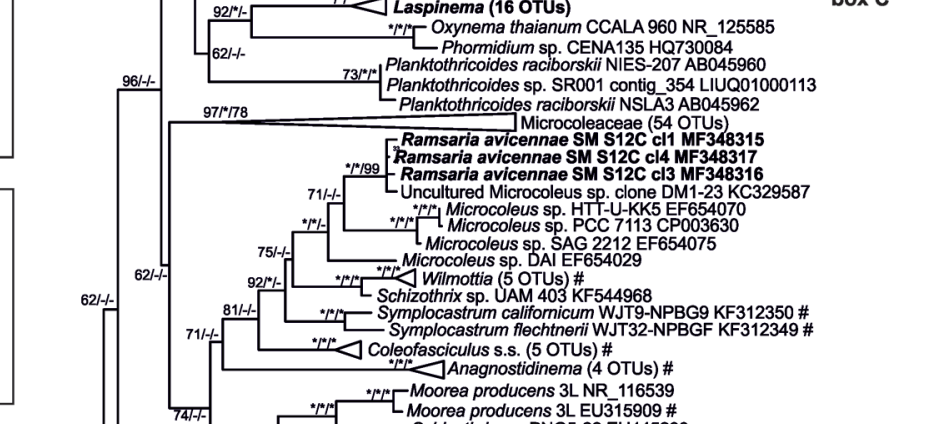

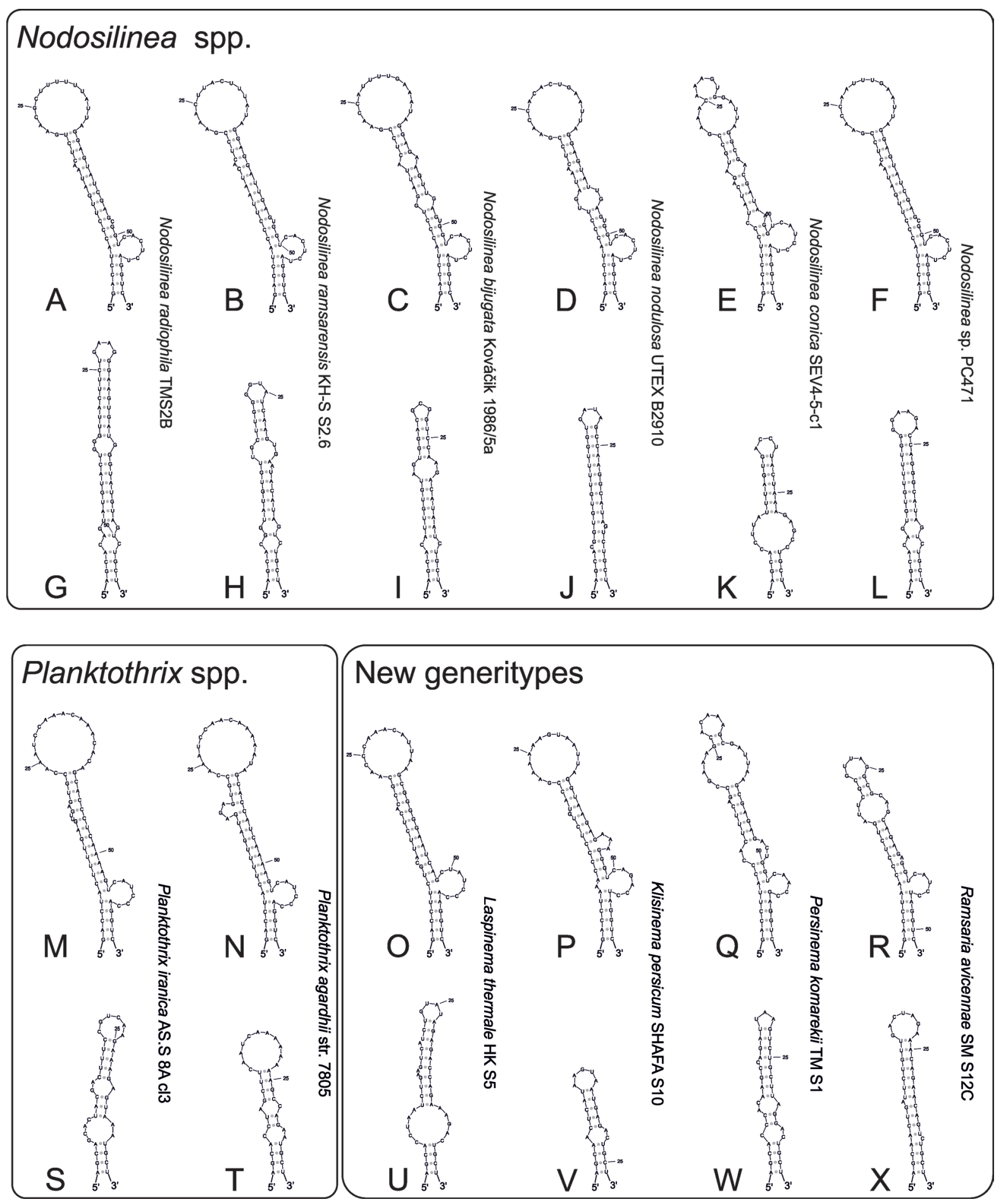

Fig. 2. Comparison of predicted secondary structures of D1-D1' (first structure in pair) and box B helices (second structure in pair) in the ITS regions for Nodosilinea spp. and Planktothrix spp., and corresponding structures for newly described generitypes: (A, G) N. radiophila sp. nov., strain TM S2B; (B, H) N. ramsarensis sp. nov., strain KH-S S2.6; (C, I) N. bijugata, strain Kováćik 1986/5a; (D, J) N. nodulosa, strain UTEX B2910; (E, K) N. conica, strain SEV4-5-c1; (F, L) N. sp., strain PC471; (M, S) P. iranica sp. nov., strain AS.S 8A; (N, T) P. agardhii, strain 7805; (O, U) Laspinema thermale sp. nov., strain HK S5; (P, V) Klisinema persicum sp. nov., strain SHAFA S10; (Q, W) Persinema komarekii sp. nov., strain TM S1; (R, X) Ramsaria avicennae sp. nov., strain SM S12C.

of aerotopes, cells size, end of trichomes and motility; ecology - Pl. iranica forms benthic mats in thermal springs and other species of the genus are mostly freshwater and planktic; and in a 16S rRNA gene sequences similarity $<98.3 \%$, which is under threshold for prokaryotic species according to YARZA et al. 2014. Unfortunately, we are not able to provide comparison of secondary structures of D1-D1' and box B helices of the ITS region with other Planktothrix species but one (Fig. 2) because of unavailability of ITS sequences 

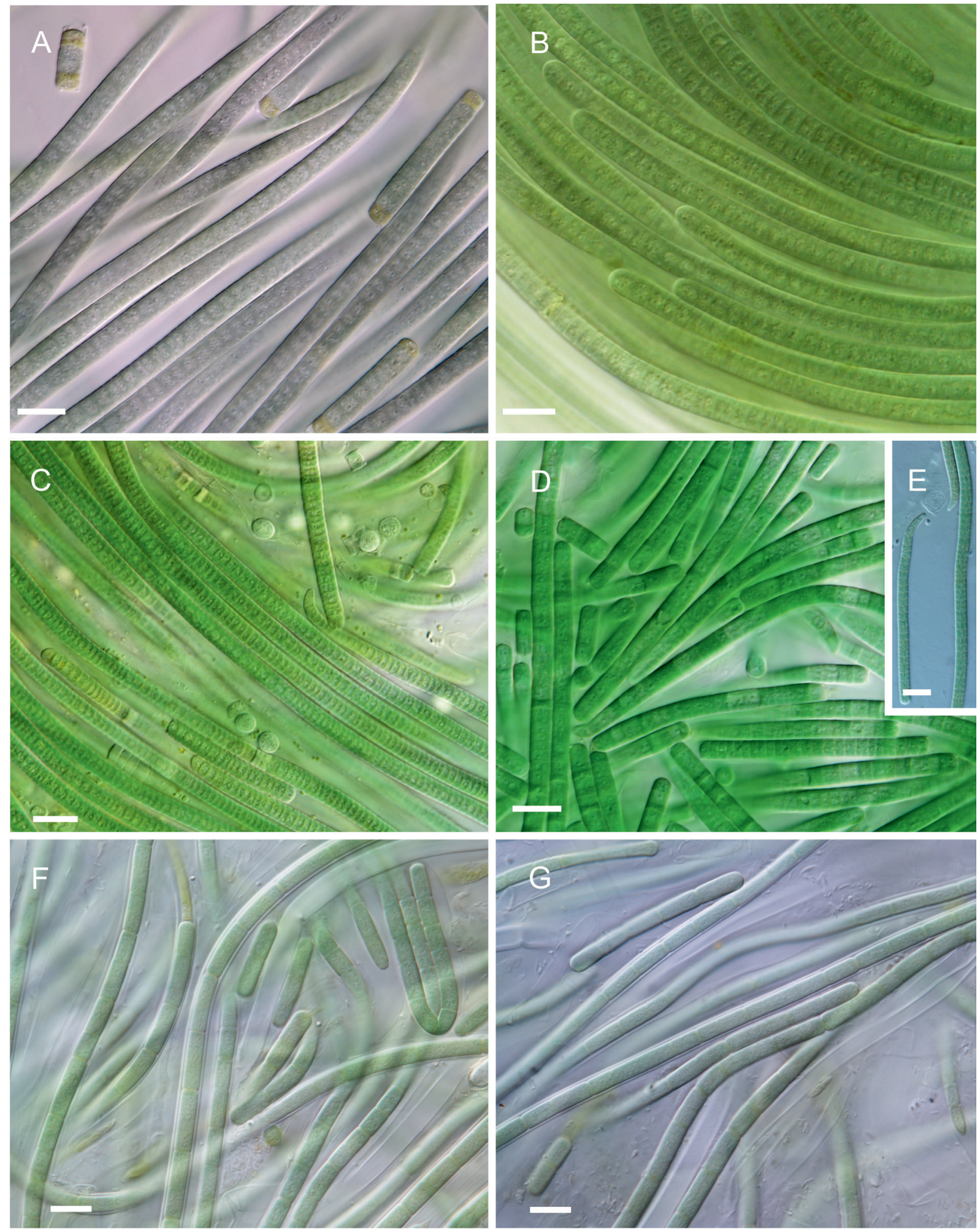

Fig. 3. (A, B) Planktothrix iranica sp. nov., strain AS S8A; (C-E) Laspinema thermale sp. nov., strain HKS5; (F, G) Ramsaria avicennae sp. nov., strain S.M. S12C.

of these taxa. Based on sequence similarities, Pl. mougeoii sensu Suda et Watanabe 2002, Pl. pseudagardhii Suda et Watanabe, and Pl. spiroides Wang et $\mathrm{Li}$ could be reclassified outside the genus Planktothrix. However, such treatment needs more supporting data and is beyond the scope of this paper.
Nodosilinea radiophila Heidari et Hauer sp. nov. (Fig. 5C, D)

Description: Solitary filaments, straight or wavy, with very thin, colorless sheath. Immotile. Trichomes strongly constricted at the cross walls, $1-2 \mu \mathrm{m}$ wide. Cells isodiametric or longer than wide, $2-5 \mu \mathrm{m}$ long, 

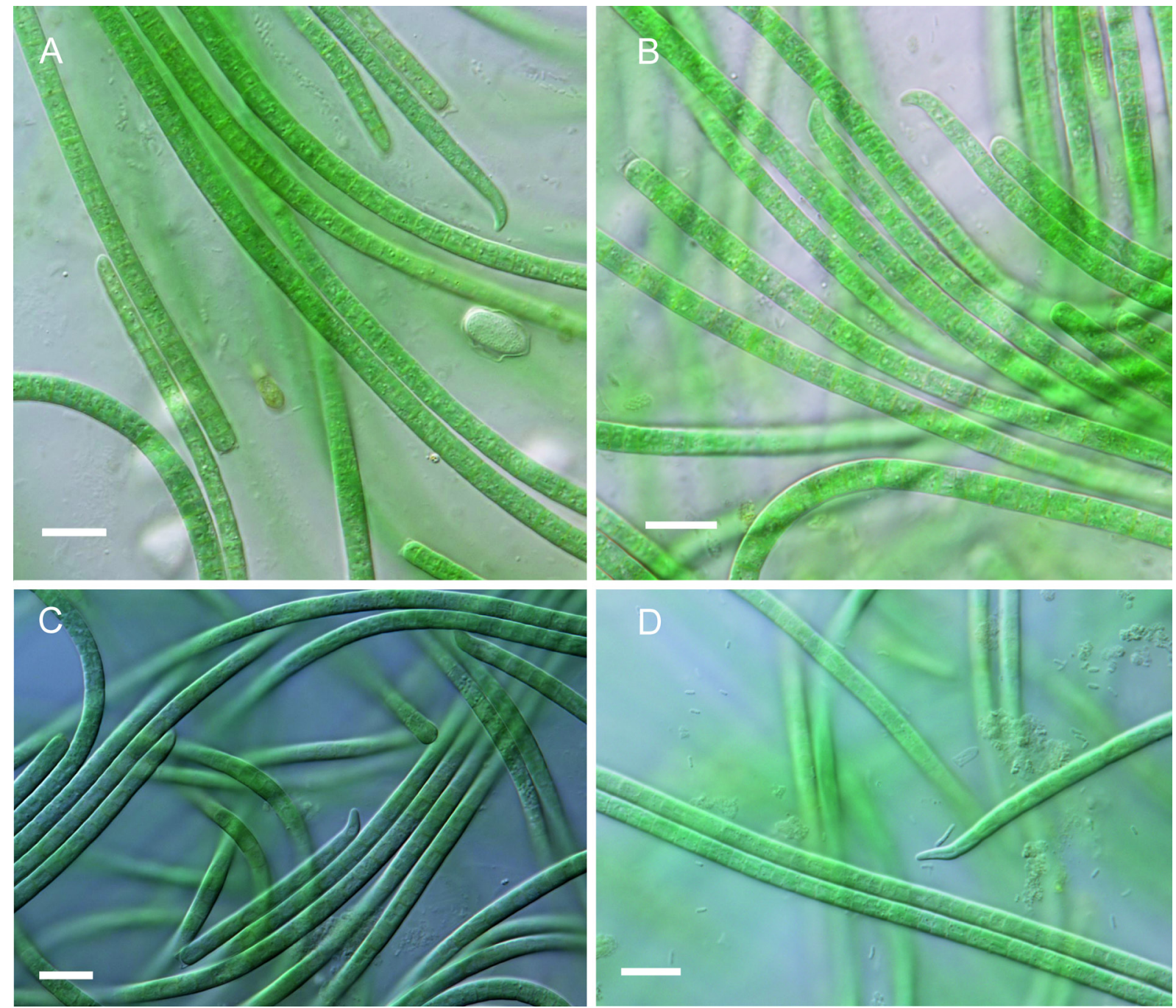

Fig. 4. (A, B) Klisinema persicum sp. nov., strain SHAFA S10; (C, D) Klisinema sp. strain CCALA 141.

with distinct granules at the cross walls. Reproduction with hormogonia.

Holotype here designated: CBFS A-83-1, an exsiccate of strain TM S2B

Habitat: Benthic mat in the thermal spring $\left(27^{\circ} \mathrm{C}\right)$ with very high natural radioactivity, Talesh Mahalleh, Ramsar, Iran.

Etymology: the specific name refers to the locality of the source material, which contains the highest radiation level measured in the world (Talesh Mahalleh, Ramsar).

From other species of Nodosilinea, this organism differs in a 16S rRNA gene sequences similarity $<98.3 \%$ and not formation of multiseriate trichomes at any time. This organism has distinct granules at the cross walls.

Nodosilinea ramsarensis Heidari et Hauer sp. nov. (Fig. 5F, G)

Description: Solitary filaments, straight, with very thin, colorless sheath. Immotile. Trichomes strongly constricted at cross walls, (0.8) 1.0-1.5 $\mu \mathrm{m}$ wide. Cells isodiametric or a little longer than wide, 1.0-2.0 $\mu \mathrm{m}$ long, usually with one prominent granule per cell. Nodules are formed very seldom, of multiseriate filaments were not observed. Reproduction with hormogonia.

Holotype here designated: CBFS A-84-1, an exsiccate of strain $\mathrm{KH}-\mathrm{S} \mathrm{S} 2.6$

Habitat: Soil around the thermal spring $\left(32^{\circ} \mathrm{C}\right)$, Khak sefid, Ramsar, Iran.

Etymology: the specific name refers to the town of origin of the source material

N. ramsarensis differs from N.radiophila in morphology $-N$. ramsarensis has short cells without granules; ecology $-N$. ramsarensis is collected from soil and $N$. radiophila is collected from the mat in thermal spring. Both currently described species differ from those described earlier also in secondary structure of $16 \mathrm{~S}$ 23S ITS region, which has been established as a good marker for species differentiation in case of high similarities of 16S rRNA gene sequences. The secondary structures of D1 - D1' and box B helices of current and 

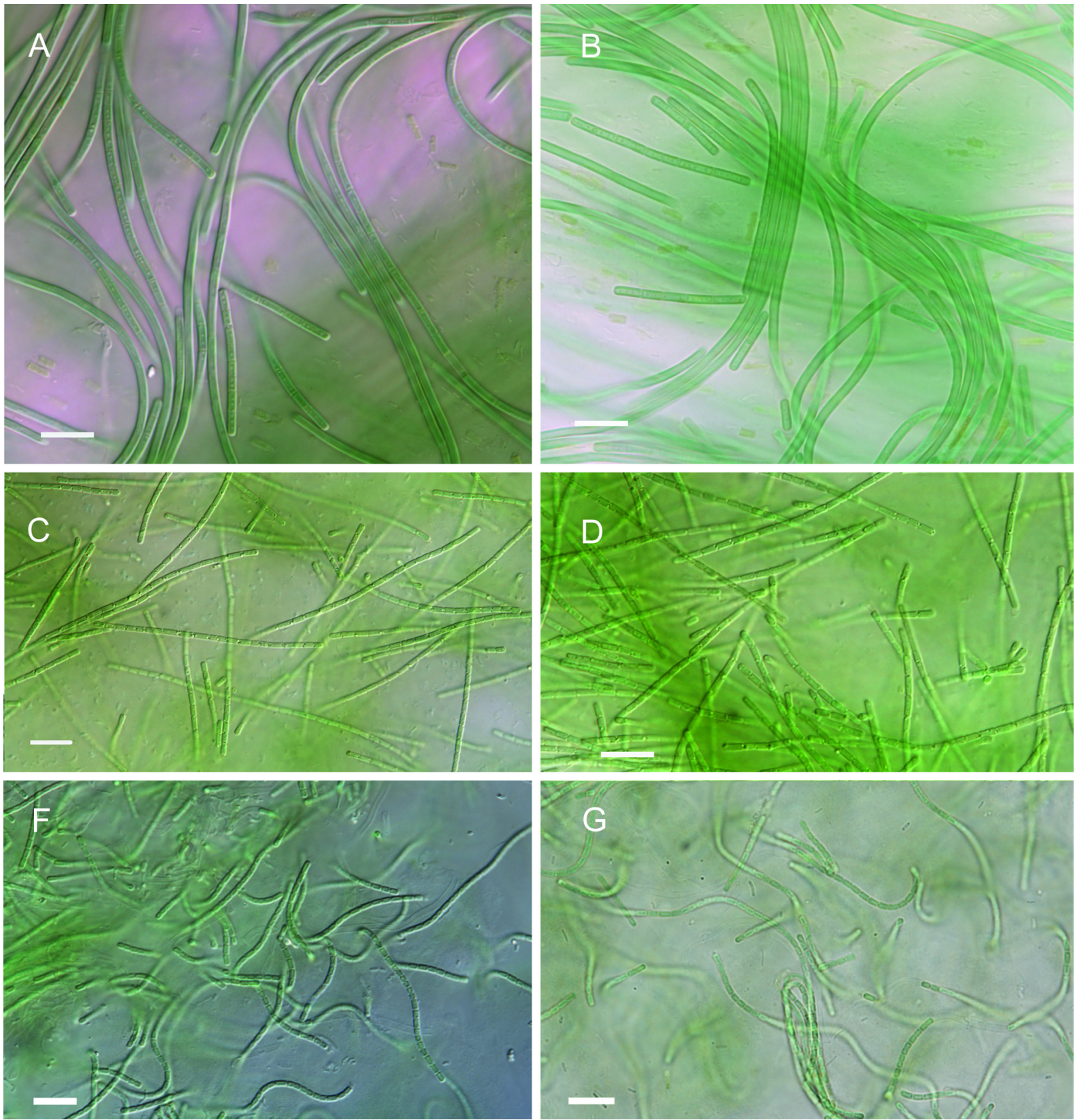

Fig. 5. (A, B) Persinema komarekii sp. nov., strain TM S1; (C, D) Nodosilinea radiophila sp. nov., strain TM S2B; (E,F) Nodosilinea ramsarensis sp. nov., strain KH-S S2.6.

proposed species are in Figure 2.

\section{Laspinema Heidari et Hauer gen. nov.}

Description: Filaments straight or wavy, blue-green or olive green. Sheath is thin, inconspicuous. Trichomes cylindrical, isopolar, unbranched, always slightly constricted at cross walls, motile. Cells shorter than wide. The terminal cell is elongated, conical, bent or straight inflated, rounded end without calyptra. Thylakoids have radial arrangement. Aerotopes are not present. Type species: Laspinema thermale Heidari et Hauer sp. nov.

Etymology: Láspi- [Gr.] $\lambda \alpha ́ \sigma \pi \eta$, mud, dirt; -nema $\left(v \eta^{\prime} \mu \alpha\right)[\mathrm{Gr}$.$] - thread; the generic name refers to habitat$ of known species and their appearance.

From the most related genus Oxynema Chatchawan, Komárek, Strunecký, Šmarda et Peerapornpisal 2012, the proposed genus differs in the level of dissimilarity, which is over $7 \%$ in $16 \mathrm{~S}$ rRNA gene; morphology - Laspinema has conical pointed as well as rounded terminal cell contrary to Oxynema, which has always sharply pointed terminal cell; motility - Laspinema is highly motile contrary to Oxynema, which is immotile.

Laspinema thermale Heidari et Hauer sp. nov. (Fig 3C, D, E)

Description: Filaments straight, in natural environment 
Table 1. Comparison of main morphological characters and ecology of Laspinema species.

\begin{tabular}{lccc}
\hline & Laspinema thermale & Laspinema etoshii & Laspinema lumbricale \\
\hline Cell width $(\boldsymbol{\mu m})$ & $3-4(5)$ & $5.5 \pm 1.5$ & $5-6(7)$ \\
Cell length $(\mu \mathrm{m})$ & $1-2.4$ & $3.0 \pm 1.0$ & $2-4$ \\
Apical cell & $\begin{array}{c}\text { Rounded, conical, shortly } \\
\text { bent }\end{array}$ & $\begin{array}{c}\text { Rounded, conical; straight or } \\
\text { bent; }\end{array}$ & Rounded, straight \\
Habitat & Thermal spring, Iran & $\begin{array}{c}\text { Hyposaline water puddles, } \\
\text { springs and wet soil, Namibia }\end{array}$ & $\begin{array}{c}\text { McMurdo Ice Shelf, Antarctica } \\
\text { Reference }\end{array}$ \\
This paper & DADHEECH et al. 2013 & CASAMATA et al. 2005 \\
\hline
\end{tabular}

forming benthic mats. Trichomes 3-4 (5) $\mu \mathrm{m}$ wide, slightly constricted on cross walls, cells always shorter than wide, terminal cell elongated, conical, bent, never acuminate.

Holotype here designated: CBFS A-85-1, an exsiccate of strain HK S5

Habitat: Benthic mat in thermal springs.

Type locality: Iran, Mahallat (Hakim, 3400'33"N; $50^{\circ} 33^{\prime} 06^{\prime \prime E}$ ), material collected by F. Heidari in 2014

Laspinema etoshii (Dadheech, Casamatta, Casper et Krienitz) Heidari et Hauer comb. nov.

Basionym: Phormidium etoshii Dadheech, Casamatta, Casper et Krienitz, Fottea 13(2): 237, 2013

Laspinema lumbricale (Casamatta, Johansen, Vis et Broadwater) Heidari et Hauer comb. nov.

Basionym: Phormidium lumbricale Casamatta, Johansen, Vis et Broadwater, Journal of Phycology 41(2): 431, 2005

The combinations made above is based on results of phylogenetic analyses and on morphological similarity in main features. Comparison of main characters of all three species is provided in Table 1 .

Notes: From Phormidium sensu stricto, i.e. the generitype Phormidium lucidum Kützing ex Gomont 1892 the newly described genus differs distinctly in morphology of terminal cells - Laspinema never has capitate end cells with calyptra neither thickened cell wall.

\section{Klisinema Heidari et Hauer gen. nov.}

Description: Trichomes straight, isopolar, unbranched, blue-green, motile, with a distinctive oscillation, not constricted or slightly constricted at the ungranulated cross-walls, usually attenuated at the ends. No sheath is present. Cells mostly isodiametric or longer than wide, rarely shorter. Terminal cells strongly bent and acute conical to conical, never pointed. Cell content homogeneous or finely granulated.

Type species: Klisinema persicum Heidari et Hauer sp. nov.

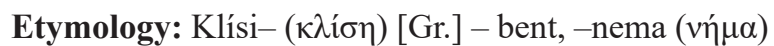
[Gr.] - thread; the generic name refers to organism appearance.

From the most similar genus Oxynema Chatchawan, Komárek, Strunecký, Šmarda et Peerapornpisal, the proposed genus differs in morphology - Klisinema has strongly bent and acute conical as well as rounded terminal cell contrary to Oxynema, which has always sharply pointed terminal cell; motility - Klisinema is highly motile contrary to Oxynema, which is immotile. From other similar genus Laspinema Heidari et Hauer gen. nov. Klisinema differs in morphology, ecology and genetic features. Klisinema has isodiametric or longer than wide cells, without sheaths, and its natural habitat is soil. These are opposite to Laspinema whose cells are never longer than wide, has a fine sheath, and lives in the form of benthic mats in springs.

Klisinema persicum Heidari et Hauer sp. nov. (Fig. 4A, B)

Description: Trichomes solitary, 3-5 um wide, bright blue-green, mostly straight, long, without sheats, intensely motile, not or slightly constricted. Cells isodiametric or longer than wide 3-5 um long. Terminal cell conical, elongated.

Holotype here designated: CBFS A-86-1, an exsiccate of strain SHAFA S10

Etymology: the species is named after the country of its origin.

Habitat: Soil around thermal springs $\left(50^{\circ} \mathrm{C}\right)$ with high radiation background.

Type locality: Iran, Mahallat (Shafa, 3400'41"N; $50^{\circ} 32^{\prime} 46^{\prime \prime E}$ ), material collected by F. Heidari in 2014

In the phylogenetic analyses, SHAFA S10 is in well supported clade with the CCALA 141 (Geitlerinema cf. acuminatum) among others (box B in Fig. 1). Both strains share similar morphology and ecology. However, SHAFA S10 and CCALA 141 are morphologically completely different from Geitlerinema 
acuminatum (Anagnostidis et Komárek) Anagnostidis (bent and spherically capitate at the end, end cell elongated up to $15 \mu \mathrm{m}$, cells $1.5-3 \mu \mathrm{m}$ wide and up to $2-4$ (6) $\times$ longer than wide). A comparison of strain SHAFA S10 with CCALA 141 has shown, that the latter strain should be also classified into the genus Klisinema. Based on figures of the strain CENA 533 in work by ANDREOTE et al. (2014) and its sequence KF246499, we suppose that also this strain could be classified into the genus, but more information would be necessary for confidence.

\section{Ramsaria Heidari et Hauer gen. nov.}

Description: Filaments solitary, cylindrical along the whole length, straight, with facultative sheath. Sheaths around single trichomes thick, firm, colorless, not lamellate. Trichomes cylindrical, isopolar, constricted at cross walls, not attenuated towards ends, unbranched. Cells up to $4 \times$ longer than wide, cylindrical, pale bluegreen, with scattered larger granules. Terminal cells rounded at the apex, without calyptra. Reproduction by disintegration of trichome into immotile segments, sometimes with participation of necridic cells.

Type species: Ramsaria avicennae Heidari et Hauer sp. nov.

Etymology: the genus name refers to the name of city of taxon's origin.

In comparison with the most similar genus Coleofasciculus (Thuret ex Gomont) Siegesmund, Johansen et Friedl in SIEGESMUND et al. 2008, the proposed genus Ramsaria differs morphologically in having always one trichome per sheath in nature as well as in vitro and also ecologically in living in freshwater environment. The level of similarity to sequences of Coleofasciculus chthonoplastes is $<93.6 \%$ in $16 \mathrm{~S}$ rRNA gene.

From other similar genus Wilmottia, our strain SM S12C is distinguished through longer cells, distinct constrictions on cross-walls, and thick sheath. The level of similarity to the reference sequence of Wilmottia murrayi (type species of the genus) is $<93.6 \%$ in $16 \mathrm{~S}$ rRNA gene.

\section{Ramsaria avicennae Heidari et Hauer sp. nov. (Fig. 3F, G)}

Description: Filaments entangled or fasciculated, flexuous, enveloped by a facultative, thick, homogeneous and colorless sheath, $4-6 \mu \mathrm{m}$ wide. Trichomes cylindrical, straight, blue-green, constricted at cross walls, not attenuated, immotile, 3.5- $4 \mu \mathrm{m}$ wide. Cells longer than wide, apical cells rounded, without calyptra 5-14 $\mu \mathrm{m}$ long. Cell content blue-green, homogenous, ungranulated cross wall. Sometimes with large granules in the cells.

Holotype here designated: CBFS A-087-1, an exsiccate of strain SM S12C.

Etymology: the species is named after medieval
Persian scholar Avicenna.

Habitat: Benthic mat in thermal springs $\left(35^{\circ} \mathrm{C}\right)$ with high radiation background.

Type locality: Iran, Ramsar (Saddat Mahalleh, $36^{\circ} 53^{\prime} 42^{\prime \prime} \mathrm{N}$; 50 $\left.41^{\prime} 30^{\prime \prime} \mathrm{E}\right)$, material collected by $\mathrm{F}$. Heidari in 2014.

\section{Persinema Heidari et Hauer gen. nov.}

Description: Trichomes solitary, isopolar, straight, slightly bent or flexuous. Cells consisting of cylindrical, elongated cells, slightly constricted at cross walls, not attenuated at the ends, without sheaths, motile. All cells with the same morphology, cylindrical, blue-green, without aerotopes. Apical cells cylindrical rounded flattened at the ends. Without calyptra, not capitate. Reproduction by disintegration of trichomes into motile hormogonia, without necridic cells.

Type species: Persinema komarekii Heidari et Hauer sp. nov.

Etymology: Persi- refers to Persia, a Middle Eastern ancient, -nema (vฑ́ $\mu \alpha)$ [Gr.] - thread

From the most similar genus Limnothrix Meffert, T.M/ $\mathrm{S} 1$ is obviously different in molecular, morphological and ecological features. T.M/S1 is without aerotopes, motile and constricted at cross walls, these are opposite to Limnothrix. Also T.M/S1 was isolated from a mat in the thermal spring and, on the contrary, L. planctonica occurs in the freshwater and is planktic.

Note: As already noted by KoMÁREK and ANAGNOSTIDIS (2005), Limnothrix is a heterogeneous genus which includes planktic, colder lakes and with polar aerotopes bearing. As the results show (Fig. 1), sequence types designated as L. planktonica make a well supported cluster separate from core Pseudanabaenaceae (cluster collapsed in Fig1 1) containing the sequence of type species of the genus, i.e. L. redekei (Van Goor) Meffert. Thus, they should be considered as a different genus. It is necessary to note, that morphotypes/strains CHAB736 and KLL-C001 (located in the sister clade to Persinema) designated as L. planktonica may not be the true L. planktonica because of different distribution, which is outside the temperate zone.

\section{Persinema komarekii Heidari et Hauer sp. nov. (Fig. 5A, B)}

Description: Trichomes solitary, straight, pale blue green, $1-2 \mu \mathrm{m}$ wide, constricted at the cross walls, without sheaths. Cells 2-5 times longer than wide ( 5-8 $\mu \mathrm{m})$. Without aerotopes. Apical cells cylindrical, rounded.

Holotype here designated: CBFS A-88-1 - dried material from strain TM S1

Etymology: the species is named in honor of Professor Jiří Komárek, a prominent Czech Phycologist and world's famous cyanobacteriologist.

Habitat: Benthic mat in thermal springs (27 $\left.{ }^{\circ} \mathrm{C}\right)$ with high radiation background. 
Type locality: Iran, Ramsar (Talesh Mahalleh, $36^{\circ} 89^{\prime} 90^{\prime \prime} \mathrm{N}$; 5067'49"E), material collected by $\mathrm{F}$. Heidari in 2014

\section{ACKNOWLEDGEMENTS}

The research was supported by grant GA CR 15-11912S, and longterm research development project no. RVO 67985939. Access to computing and storage facilities owned by parties and projects contributing to the National Grid Infrastructure MetaCentrum, provided under the programme "Projects of Large Infrastructure for Research, Development, and Innovations" (LM2010005), is greatly appreciated.

\section{REFERENCES}

AliYu, A.S. \& Termizi Ramli, A. (2015): The world's high background natural radiation areas (HBNRAs) revisited: A broad overview of the dosimetry, epidemiological and radiobiological issues. - Radiat. Meas. 73: 51-59.

ANDreote, A.P.D.; VAZ, M.G.M.V; GenuÁRIO, D.B.; Barbiero, L.; Rezende-Filho, A.T. \& Fiore, M.F. (2014): Nonheterocytous cyanobacteria from Brazilian saline-alkaline lakes. - Journal of Phycology 50: 675-684

Anitori R.P.; Trott. Ch.; Saul D.J.; Berquist P.L. \& WaLter M.R.(2002): A Culture-Independent Survey of the Bacterial Community in a Radon Hot Spring. Astrobiology 2: 255-270

Arman, M.; Riahi, H.; Yousefzadi, M. \& Sonboli, A. (2014): The Study of Cyanobacterial Flora from Lamazan Hot Springs of West Hormozgan, Iran. - J. Life Sci. Biomed. 4: 177-182.

Beck, C.; Knoop, H.; Axmann, I.M. \& Steuer, R. (2012): The diversity of cyanobacterial metabolism: genome analysis of multiple phototrophic microorganisms. BMC Genomics 13: 56.

Beitollahi, M.; Ghiassi-Nejad, M. \& Esmaeli, A. (2007): Radiological studies in the hot spring region of Mahallat, Central Iran. - Radiat. Prot. Dosim. 123: 505-508.

Bravakos, P.; Kotoulas, G.; Sharaki, K.; Pantazidou, A. \& ECONOMOU-Amilli, A. (2016): A polyphasic taxonomic approach in isolated strains of Cyanobacteria from thermal springs of Greece. - Mol. Phylogenet. Evol. 98: 147-160.

CALDERón, R.M. (2014): Ecology of Hot Spring Microbial Mats: Diversity, Microheterogenicity, and Biogeography [PhD Thesis]. - 179 pp., Universitat Autònoma de Barcelona, Barcelona, Spain.

CAntonati, M.; Füreder, L.; GreCKe, R.; JÜTtNer, I. \& Cox, E.J. (2012a): Crenic habitats, hotspots for freshwater biodiversity conservation: toward an understanding of their ecology. - Freshwater Science 31:463-480.

Casamatta, D.; Stanić, D.; Gantar, M. \& Richardson L. L. (2012): Characterization of Roseofilum reptotaenium (Oscillatoriales, Cyanobacteria) gen. et sp. nov. isolated from Caribbean black band disease. - Phycologia 51: 489-499.

Castenholz, R.W. (1996): Endemism and biodiversity of thermophilic cyanobacteria. - Nova Hedwigia 112: 33-47.

Chatchawan, T.; Komarek, J.; Strunecky, O.; Šmarda, J.
\& PeerapornPisal Y. (2012): Oxynema, a new genus separated from the genus Phormidium (Cyanophyta). - Cryptogamie, Algologie 33: 41-59.

Crispim, C. A.; Christine, C. \& Gaylarde, P. M. (2004): Gaylarde, Biofilms on church walls in Porto Alegre, RS, Brazil, with special attention to cyanobacteria. Int. Biodeterior. - Biodegradation 54: 121-124.

Dadheech, P.K.; Gernot, G.; Casper, P.; Kotut, K.; Junqueira Mazzoni, C.; Mbedi, S. \& Krientiz, L. (2013): Cyanobacterial diversity in the hot spring, pelagic and benthic habitats of a tropical soda lake. FEMS Microbiol. Ecol. 85: 389-401.

Darriba, D.; Taboada, Gl.; Doallo, R. \& Posada, D. (2012): jModelTest 2: more models, new heuristics and parallel computing. - Nature Methods 9: 772.

Ding, Y.; Chan, D.Y. \& Lawrence, C.E. (2004): Sfold web serverfor statistical folding and rational design of nucleic acids. - Nucleic Acid Research 32: W135-141.

Finsinger, K.; Scholz, I.; Serrano, A.; Morales, S.; UribeLorio, L.; Mora, M.; SitTenfeld, A.; Wechesser, J. \& Hess, W.R. (2008): Characterization of truebranching cyanobacteria from geothermal sites and hot springs of Costa Rica. - Environ. Microbiol. 10: 460-473.

Forte, M.; Rusconi, R.; Badalamenti, P.; Bellinzona, S.; Gollini, R.; Maltese, S.; Romeo, C. \& Sgorbati, G. (2004): The monitoring of tap waters in Milan: planning, methods and results. - Radiat. Prot. Dosim. 111: 373-376.

Geesey, G.G.; Barkay, T. \& King, S. (2016): Microbes in mercury-enriched geothermal springs in Western North America. - Sci. Total Environment 569-570: 321-331.

Ghozzi, K.; Zemzem, M.; Ben Dhiab, R.; Challouf, R. \& YAHIA, A. (2013): Screening of thermophilic microalgae and cyanobacteria from Tunisian geothermal sources. - J. Arid Environment 97:14-17.

Glazier, D.S. (2009): Springs. - In: Likens, G.E. (ed.): Encyclopedia of Inland Waters 1. - pp. 734-755, Academic Press Elsevier, Oxford, UK.

Hall, T.A. (1999): BioEdit: a user-friendly biological sequence alignment editor and analysis program for Windows 95/98/NT. - Nucl. Acids. Symp. Ser. 41: 95-98.

HaŠLER，P.; DvořÁK， P.; JohanSEn， J.R.; Kitner, M.; ONDŘEJ, V. \& PoulíčKovÁ, A. (2012): Morphological and molecular study of epipelic filamentous genera Phormidium, Microcoleus and Geitlerinema (Oscillatoriales, Cyanophyta/Cyanobacteria).

Fottea, Olomouc 12: 341-356.

Heidari, F.; Riahi, H.; Yousefzadi, M. \& Shariatmadari, Z. (2013): Morphological and phylogenetic diversity of cyanobacteria in four hot springs of Iran. - Iran J. Bot. 19: 162-172.

Hongmei, J.; Lacap Jonathan, C. Aitchison Donnabella, C.; Sompong, Y. P. U. \& Pointing, S.B. (2005): Community phylogenetic analysis of moderately thermophilic cyanobacterial mats from China, the Philippines and Thailand. - Extremophiles 9: 325-332.

ICRP (1991): 1990 Recommendations of the International Commission on Radiological Protection. - ICRP Publication 60. Ann. ICRP 21: 1-249.

ICRP (2007): The 2007 Recommendations of the International Commission on Radiological Protection. - Annals of 
the ICRP 37: 1-332.

JaAkKola, S.T.; RAVANATti, J.J.; OKSANEn, H.M. \& BAMFORD, D.H. (2016): Buried alive: microbes from ancient halite. - Trends in Microbiol. 24:148-160.

Katoh, K. \& Toh, H. (2010): Parallelization of the MAFFT multiple sequence alignment program. Bioinformatics 26: 1899-1900.

King, S.A.; BehnKe, S.; Slack, K.; Krabbenhoft, D.P.; Nordstrom, D.K.; Burr, M.D. \& Strigl, R.G. (2006): Mercury in water and biomass of microbial communities in hot springs of Yellowstone National Park, USA. - Appl. Geochem. 21: 1868-1879.

KomÁReK, J. \& ANAGnostidis, K. (1999): Cyanoprokaryota, 1. Teil: Chroococcales. - In: EtTL, H.; GäRTNER, G.; Heynig, H. \& Mollenhauer, D. (eds): Susswasserflora von Mitteleuropa. - 548 pp., Gustav Fischer Verlag, Stuttgart - Jena..

KomÁReK, J. \& ANAGnostidis, K. (2005): Cyanoprokaryota. 2.Teil: Oscillatoriales. -In: BÜDEL, B.; KRIENITZ, L.; Gartner, G. \& Schagerl, M. (eds): Süsswasserflora von Mitteleuropa. - 759 pp., Elsevier, Munich.

KomáReK, J. (2016b): Polyphasic approach for the taxonomy of cyanobacteria: principles and applications. European Journal of Phycology 51: 1-8.

Komárek, J.; Kaštovský, J.; Mareš, J. \& Johansen, J. R. (2014): Taxonomic classification of cyanoprokaryotes (cyanobacterial genera) 2014, using a polyphasic approach. - Preslia 86: 295-335.

Komárek, J.; Kaštovský, J.; Ventura, S.; Turicchia, S. \& Šmarda, J. (2009): The cyanobacterial genus Phormidesmis. - Algological Studies 129: 41-59.

Kumar, S.; Stecher, G. \& Tamura, K. (2016): MEGA7: Molecular evolutionary genetics analysis version 7.0 for bigger datasets. - Mol. Biol. Evol. 33: 1870-1874.

Lamprinou, V.; HernándeZ-Mariné, M.; Pachiadakic, M.G.; Kormasc, K.A.; Economou-Amilli, A. \& Pantazidou, A. (2013): New findings on the truebranched monotypic genus Iphinoe (Cyanobacteria) from geographically isolated caves (Greece). - Fottea, Olomouc 13: 15-23.

Guindon, S. (2010): PhyTime: "Bayesian estimation of divergence times from large sequence align-ments". Mol. Biol. Evol. 27: 1768-81.

Gouy, M.; Guindon, S. \& Gascuel, O. (2010): SeaView version 4: a multiplatform graphical user interface for sequence alignment and phylogenetic tree building. Mol. Biol. Evol. 27: 221-224.

LiU, C.; WANG, X. \& Sun, C. (2016): Acclimation of Antarctic Chlamydomonas to the sea ice environment: a transcriptomic analysis. - Extremophiles 20:437-450.

Machado-de-Lima, N.M.; Martins, M.D. \& Branco, L.H.Z. (2017): Description of a tropical new species of Wilmottia (Oscillatoriales, Cyanobacteria) and considerations about the monophyly of $W$. murrayi. - Phytotaxa 307: 043-054.

MahaJAN, G.B. \& BALACHANDRAN, L. (2017): Sources of antibiotics: Hot springs. - Biochemical Pharmacology 134: $35-41$.

LANE, D.J. (1991): 16S/23S rRNA sequencing. - In: Stackebrandt, E. \& Goodfellow, M. (eds): Nucleic acid techniques in bacterial systematics. - pp. 115175., John Wiley and Sons, New York, NY.

McGregor, G.B. \& Paul Rasmussen, J. (2008): Cyanobacterial composition of microbial mats from an Australian thermal spring: a polyphasic evaluation. - FEMS Microbiol. Ecol. 63: 23-35.
MoniewsKi, P. (2004): Źródła Okolic Łodzi (springs of Łódź Surroundings). - Acta Geographica Lodziensia. 87: $1-140$.

Mortazavi, S.M.J. \& Mozdarani, H. (2012): Is it time to shed some light on the black box of health policies regarding the inhabitants of the high background radiation areas of Ramsar? - Iran J. Radiat. Res. 10: $111-116$.

Mortazavi, S.M.J.; Ghiassi-Nejad, M. \& Ikushima, T. (2002): Do the Findings on the Health Effects of Prolonged Exposure to Very High Levels of Natural Radiation Contradict Current Ultra-conservative Radiation Protection Regulations? - International Congress Series 1236: 19-21.

Nowicka KrawczyK, P. \& ŻelaZna-WieczoreK, J. (2017): Dynamics in cyanobacterial communities from a relatively stable environment in an urbanised area (ambient springs in Central Poland). - Sci. Total Environ. 579: 420-429.

Nugent, P.; Shaw, J.A. \& Vollmer, M. (2015): Colors of thermal pools at Yellowstone National Park. - Appl. Optics 54: 128-139.

Oren, A.; Ionescu, D.; Hindiyeh,M.Y \& Malkawi, H.I. (2009): Morphological, phylogenetic and physiological diversity of cyanobacteria in the hot springs of Zerka Ma'in, Jordan. - Bio. Risk 3: 69-82.

Perkerson, R.B.; Johansen, J.R; KováčIK, L.; Brand, J.; KašTovskÝ, J. \& CASAMATTA, D.A. (2011): A unique pseudanabaenalean (cyanobacteria) genus Nodosilinea gen. nov. based on morphological and molecular data. - J. Phycol. 47:1397-1412.

Prabha, R.; Singh, D.P.; Somvanshi, P. \& Rai, A. (2016): Functional profiling of cyanobacterial genomes and its role in ecological adaptations. - Genomics Data 9: 89-94.

Rahman, O.; Pfitzenmaier, M.; Pester, O.; Morath, S.; Cummings, S.P.; Hartung, T. \& Sutcliffe, C. (2008): Macroamphiphilic components of thermophilic actinomycetes: identification of lipoteichoic acid in Thermobifida fusca. - J. Bacteriol. 191: 152-160.

Roeselers, G.; Norris, T.B.; CASTenholz, R.W.; RYSGAARD, S.; Glud, RN.; KüHL, M. \& Muyzer, G. (2007): Diversity of phototrophic bacteria in microbial mats from Arctic hot springs (Greenland). - Environ. Microbiol. 9: 26-38.

Ronquist, F.; Teslenko, M.; VAn der Mark, P.; Ayres, D. L.; Darling, A.; Hohna, S.; Larget, B.; Liu, L.; Suchard, M. A. \& Huelsenbeck, J. P. (2012): MrBayes 3.2: efcient Bayesian phy-logenetic inference and model choice across a large model space. - Syst. Biol. 61:539-42.

SANusi, M.S.M.; LeE, M.H. \& RAMLI, A. (2016): Investigation of geological and soil inuence on natural gamma radiation exposure and assessment of radiation hazardsin Western Region,Peninsular Malaysia. - Environ. Earth. Sci. 75:485.

Satyanarayana, T.; Raghukumar, C. \& ShivajI, S. (2005): Extremophilic microbes: Diversity and perspectives. - Current science. 89: 78-90.

ScIUTo, K. \& Moro, I. (2016): Detection of the new cosmopolitan genus Thermoleptolyngbya (Cyanobacteria, Leptolyngbyaceae) using the 16S rRNA gene and 16S-23S ITS region. - Mol. Phylogenet. Evol. 105: $15-35$.

ShariatMadari, Z.; Riahi, H.; AbDi, M.; SEYed Hashtroudi, M. \& GHASSEMPOUR, A.R. (2015): Impact of 
cyanobacterial extracts on the growth and oil content of the medicinal plant Mentha piperita L. - J. Appl. Phycol. 27: 2279-2287.

Shivlata, L. \& Satyanarayana, T. (2015): Thermophilic and alkaliphilic Actinobacteria: biology and potential applications. - Front Microbiol. 6: 1014.

Siangbood, H. \& Ramanujam, P. (2011): A report on thermophilic Cyanophyta (Cyanobacteria) from Jakrem hot spring, Meghalaya. - Int. J. Algae. 13: 178-185.

SohraBI, M. (1993): Recent Radiological Studies of High Level Natural Radiation Areas of Ramsar. - In: Proceedings of the International Conference on High Levels of Natural Radiation, 1990, Ramsar, Iran. - pp. 39-47, IAEA Publication Series, IAEA, Vienna.

Sohrabi, M. (1994): Proceedings of the international conference on high levels of natural radiation. - Radiat. Meas. 23: 261-262.

Sohrabi, M. (1998): The state-of-the-art on worldwide studies in some environments with elevated naturally occurring radioactive materials (NORM), invited paper. - Appl. Radiat. Isot. 49: 169- 188.

Sohrabi, M. (2013a): Response to the letter of H. Abdollahi. - Radiat. Meas. 59: 290e292.

SoHRABI, M. (2013b): World high background natural radiation areas: need to protect public from radiation exposure. - Radiat. Meas. 50: 166-171.

Sompong, U.; Hawkins, P.R.; Besley, C. \& Peerapornpisal, Y. (2005): The distribution of cyanobacteria across physical and chemical gradients in northern Thailand. - FEMS Microbiol. Ecol. 52: 365-376.

Spitale, D.; Leira, M.; Angeli, N. \& Cantonati, M. (2012a): Environmental classification of springs of the Italian Alps and its consistency across multiple taxonomic groups. - Freshwater Science 31: 563-574.

Spitale, D.; Lencioni, V. \& Cantonati, M. (2012b): Relative importance of space and time in determining the biotic structure in the upper part of spring-fed streams. - Freshwater Science 31: 586-598.

Stanier, R.Y.; Kunisawa, R.; Mandel, M. \& CohenBAZIRE, G. (1971): Purification and properties of unicellular blue- green algae (order Chroococcales). - Bact. Rev. 35: 171-205.

StruneckÝ, O.; Elster, J. \& KomÁreK J. (2010): Phylogenetic relationships between geographically separate Phormidium cyanobacteria: is there a link between north and south polar regions? - Polar. Biol. 33: $1419-1428$.

Strunecký, O.; Elster, J. \& KomÁreK J. (2011): Taxonomic revision of the freshwater cyanobacterium "Phormidium" murrayi $=$ Wilmottia murrayi. - Fottea 11: $57-71$.

StruneckÝ, O.; KomáReK,J. \& ŠMArda, J. (2014): Kamptonema (Microcoleaceae, Cyanobacteria), a new genus derived from the polyphyletic Phormidium on the basis of combined molecular and cytomorphological markers. - Preslia 86:193-207.

STRUNECKÝ, O.; BOHUNICKÁ, M.; JOHANSEN, J.R.; ČAPKOVÁ, K.; RaAbová, L.; DVořáK, P. \& KomÁreK, J. (2017): A revision of the genus Geitlerinema and a description of the genus Anagnostidinema gen. nov. (Oscillatoriophycidae, Cyanobacteria). - Fottea, Olomouc 17: 114-126. DOI: 10.5507/fot.2016.025.

Suda, S.; Watanabe, M.M.; Otsuka, S.; Mahakahant, A.; Yongmanitchai, W.; Nopartnaraporn, N.; LiU, Y. \& DAY, J.G. (2002): Taxonomic revision of water-bloom-forming species of oscillatorioid cyanobacteria.
- Int. J. Syst. Evol. Microbiol. 52: 1577-1595.

Tifinopoulos, J.; Nguyen, T.-P.; von Haeseler, A. \& Minh B.Q. (2016): W-IQ-TREE: a fast online phylogenetic tool for maximum likelihood analysis. - Nucleic Acids Research 44: 232-235.

UNSCEAR (2000a): Biological Effects at Low Radiation Doses. - pp. 75-175, United Nations, New York.

UNSCEAR (2000b): Sources and Effects of Ionizing Radiation, Report to the General Assembly of the United Nations with Scientific Annexes. - 653 pp., United Nations, New York.

WARD, D.M.; Ferris, M.J.; Nold, S.C. \& Bateson, M.M. (1998): A natural view of microbial biodiversity within hot spring cyanobacterial mat communities. Microbiol. Mol. Biol. Rev. 62: 1353-1370.

Ward, D.M.; Castenholz, R.W. \& Miller, S.R. (2012): Cyanobacteria in Geothermal Habitats. - In: Whitton, B.A. (ed.): Ecology of Cyanobacteria II: Their Diversity in Space and Time. - pp. 39-63, Springer, Heidelberg.

Wilmotte, A. Van der Auwera, G. \& Dewachter, R. (1993): Structure of the 16S ribosomal-RNA of the thermophilic cyanobacterium Chlorogloeopsis HTF (Mastigocladus laminosus HTF) strain PCC7518, and phylogenetic analysis. - FEBS Lett. 317: 96-100.

Yilmaz, M.; Phlips, E. J. \& Tillett, D. (2009): Improved methods for the isolation of cyanobacterial dna from environmental samples. - J. Phycol. 45: 517-21.

Zakaria, A.M. \& Abdulrahman, M.N. (2008): Toxic cyanobacteria and cyanotoxins in public hot springs in Saudi Arabia. - Toxicon. 51: 17-27.

Zammit, G.; Billi, D.\& Albertano, P. (2012): The subaerophytic cyanobacterium Oculatella subterranea (Oscillatoriales, Cyanophyceae) gen. et sp. nov.: a cytomorphological and molecular description. - Eur.J. Phycol 47: 341-354.

ŻelazNA-WieczoreK, J. (2011): Diatom flora in springs of Łódź Hills (Central Poland), biodiversity, taxonomy, and temporal changes of epipsammic diatom assemblages in springs affected by human impact. - In: WitKowski, A. (ed.): Diatom Monographs, 13. - 438 pp., ARG. Gantner Verlag K.G, Ruggell, Lichtenstein.

WeBB, V.L. \& MAAs, E.W. (2002): Sequence analysis of $16 \mathrm{~S}$ rRNA gene of cyanobacteria associated with the marine sponge Mycale (Carmia) hentscheli. - FEMS Microbiol Lett. 207: 43-47.

\section{Supplementary materia}

the following supplementary material is available for this article:

Table S1. Physio-chemical characteristics of soil and water in sampled thermal springs in Iran.

This material is available as part of the online article (http:// fottea.czechphycology.cz/contents)

\section{(C) Czech Phycological Society (2018)}

Received August 8, 2017

Accepted December 12, 2017 